\title{
ПИТАННЯ ФОРМУВАННЯ ПЕДАГОГІЧНОЇ КОМПЕТЕНТНОСТІ МАЙБУТНІХ УЧИТЕЛІВ ТЕХНОЛОГІЙ У ПРОЦЕСІ МОДЕЛЮВАННЯ СИТУАЦІЙ ПРЕВЕНТИВНОЇ СПРЯМОВАНОСТІ
}

Кулінка Ю. С. Питання формування педагогічної компетентності майбутніх учителів технологій у процесі моделювання ситуачій превентивної спрямованості.

У статті проаналізовано питання формування педагогічної компетентності майбутніх учителів технологій у процесі моделювання ситуачій превентивної спрямованості, розглянуто основні підходи до проблеми моделювання педагогічних ситуащій, описано труднощі, що виникають у процесі проектування та подано приклад ситуачій превентивної спрямованості під час вивчення загальної педагогіки.

Ключові слова: професійно-педагогічна підготовка, педагогічна компетентність, моделювання, педагогічні ситуачії, моделювання педагогічних ситуацій, групи ситуаиій превентивної спрямованості.

Кулинка Ю. С. Вопросы формирования педагогической компетентности будуших учителе в прочессе моделирования ситуаций превентивной направленности.

B статье анализируются вопросы формирования педагогической компетентности будущих учителей технологии в прочессе моделирования ситуаций превентивной направленности, рассматриваются основные подходы к проблеме моделирования педагогических ситуаций, описываются трудности, возникающие в прочессе проектирования и подается пример ситуаций превентивной направленности при изучении общей педагогики.

Ключевые слова: профессионально-педагогическая подготовка, педагогическая компетентность, моделирование, педагогические ситуации, моделирование педагогических ситуаций, группы ситуаџий превентивной направленности.

Kulinka $Y$. The questions of formation of future teachers' pedagogical competence in the process of modeling situations with preventive orientation.

The article examines the issues of formation of future teachers' pedagogical competence, technology in the simulations preventive orientation, the basic approaches to the problem of modeling pedagogical situations are depicted here, the difficulties are described which are appearing in the process of designing and the example of situations with preventive orientation in the study of general pedagogy is given.

Key words: professional pedagogical teacher's training, pedagogical competence, modeling, pedagogical situations, modeling pedagogical situations, groups of situations with preventive orientation.

Постановка проблеми в загальному вигляді. Реформування системи освіти України в контексті соціальних перетворень зумовлює необхідність іiі наближення до рівнів світових освітніх стандартів. Стратегічні завдання розбудови системи вищої освіти зумовлюють необхідність розв'язання наукових і практичних проблем, пов'язаних саме з професійно-педагогічною підготовкою майбутнього вчителя технологій до превентивної діяльності.

У сучасній психолого-педагогічній літературі наявні різні підходи до визначення сутності професійно-педагогічної підготовки вчителя: як «певного рівня сформованості спеціальних умінь, навичок, необхідних для виконання успішної професійної діяльності», як «готовності до виконання 
професійно-педагогічної діяльності» (Л. Левітов, Р. Нізамов), як «сукупності професійно-педагогічних знань, умінь, навичок та особистісних якостей педагога» (Л. Савченко), як «системи змістовно-педагогічних організаційнометодичних заходів, спрямованих на забезпечення готовності майбутнього педагога до педагогічної діяльності» (Л. Кондрашова).

Основна задача вищих педагогічних навчальних закладів - підготувати студентів до майбутньої навчально-виховної діяльності. Така підготовка включає: оволодіння студентами необхідними базовими знаннями 3 певної кваліфікації, формування необхідних професійних умінь і навичок та особистісних якостей тощо. Поряд 3 цим сучасне звернення до компетентнісного підходу в підготовці майбутніх учителів грунтується на розумінні того, що нині важливо акцентувати увагу на фундаментальних знаннях, процесуальній стороні засвоєння їх студентами, враховувати особистісний аспект потреб, утруднень, відкриття нових знань, тобто проектуванні соціальної стратегії.

Зв'язок проблеми 3 науковими програмами, планами, темами. Підготовка майбутнього професійно компетентного вчителя в умовах гуманізації та технологізації педагогічної освіти є актуальним завданням і предметом наукових дискусій i роздумів науковців, дослідження яких спрямовуються на виявлення змісту та сутності педагогічної компетентності як орієнтація вищої педагогічної освіти та особистість майбутнього вчителя (В. Болотова, І. Гушлевська, I. Зимня, І. Зязюн, Л. Кондрашова та інші).

Мета статті - обгрунтувати питання формування педагогічної компетентність майбутніх учителів технології у процесі моделювання педагогічних ситуацій превентивної спрямованості.

Виклад основного матеріалу. Як підтверджують численні педагогічні дослідження (С. Барбіна, Н. Кузьміна, А. Маркова, В. Маслов, О. Пєхота та інші), в образі професійно компетентного вчителя повинні гармонізуватися інструментальні компоненти (знання, вміння, активність, самостійність, індивідуальність) та професійні якості (тактовність, комунікативність, доброзичливість, емоційна врівноваженість тощо). Н. Дергунова під формуванням професійної компетентності розуміє процес впливу, що передбачає деякий стандарт, на який орієнтується суб'єкт впливу; процес, під яким розуміється деяка завершеність, досягнення певного рівня стандарту. Формування професійної компетентності - керований процес становлення професіоналізму, тобто це освіта і самоосвіта спеціаліста.

Вихідною позицією визначення цього поняття, на нашу думку, може стати інтегрований комплексний підхід, що має спиратися на теорії професійної компетентності, розробленої відомими науковцями з проблем професійної підготовки вчителя $\quad$ В. Сластьоніним, $\quad$. Шияновим та А. Марковою. За визначенням В. Введенського, поняття «педагогічна компетентність» включає «знання, уміння, навички, а також способи i прийоми їх реалізації в діяльності, в спілкуванні, в розвитку (саморозвитку) особистості» [3, с 52]. Зміст професійної компетентності педагога 
характеризується процесуальними й результативними показниками і визначається як його здатність та готовність виконувати особисту професійну діяльність.

Нині у зв’язку зі зростанням вимог до освітньої та професійної підготовки молодого вчителя виникла необхідність здійснювати перехід до індивідуального підходу в навчанні, розвитку творчих здібностей майбутніх спеціалістів, спираючись на їх самостійну роботу, активні форми та методи навчання.

Формування педагога творчого, ініціативного, самокритичного може бути здійснено лише тоді, коли майбутній учитель у процесі навчання у педагогічному ВН3 буде поставлений в умови, наближені до його практичної діяльності за допомогою активних методів навчання, що готують його до співпраці з учнями.

У педагогіці метод моделювання має на меті створення педагогічних ситуацій, які 6 дозволяли вирішити певну проблему. Педагогічне моделювання є невід'ємною формою всіх видів педагогічної роботи: дослідження, діагностики, консультування, превенції та корекції.

Останнім часом проблема моделювання в педагогіці опікуються такі науковці, як: С. Архангельський, Р. Габдреєв, Л. Кондрашова, Н. Кузьміна, Ю. Кулюткін, Л. Спірін, Г. Сухобська та інші.

Н. Бордовська, А. Реан зазначають, що моделювання - це процес побудови та дослідження моделей. Застосування моделювання як методу виховання та навчання приводить до суттєвого підвищення ефективності навчально-виховного процесу. У результаті досліджень цими авторами виявлено, що у процесі традиційного навчально-виховного процесу діяльність моделювання не формується масово. Відповідно, Н. Бордовська та А. Реан рекомендують розглядати моделювання як метод навчання i виховання та цілеспрямовано його використовувати [2, с.146].

Окрім того, моделювання у педагогічних дослідженнях розглядають як управління пізнавальною діяльністю студентів під час розв'язування педагогічних ситуацій (Н. Кузьміна, Л. Спірін та інші); для полегшення засвоєння навчального матеріалу та формування практичних умінь і навичок (С. Каменецький, Л. Кондрашова, А. Шибанов та інші).

На основі аналізу досліджень О. Березюк, Л. Кондрашової, Ю. Мальованого можна виокремити такі основні напрями використання методу моделювання гносеологічний, аналітичний, загальнометодологічний, модельно-інформаційний, психологічний. 3-поміж позитивних ознак методу дослідники виокремлюють: можливість виходу за межу чуттєвого відображення наявних суттєвих зв’язків речей; наукове передбачення ходу подій; свідому постановку вироблених планів і проектів діяльності; перетворення ідеальних моделей дій у практичні дії та ідеальних побудов у реальні.

Отже, моделювання, створюючи певну проблему, заохочує швидке реагування та розв'язання їі, тим самим формуючи певні особистісні та професійні якості студента, які допоможуть йому в подальшій шкільній роботі. 
Оскільки темою нашого дослідження $є$ моделювання педагогічних ситуацій превентивної спрямованості як засобу формування педагогічної компетентності в майбутніх учителів технологій, ми пропонуємо розглянути термін «педагогічна ситуація».

У психолого-педагогічній літературі наявні різні підходи визначення терміна педагогічна ситуація. Так, Л. Спірін, зокрема, зазначає, що педагогічна ситуація допомагає виявити сутність явищ навчання та виховання i шляхів досягнення педагогічної мети, тому педагогічну ситуацію можна вважати комплексом умов педагогічної діяльності, що виникають у процесі навчально-виховної роботи [7].

М. Махмутов, Р. Нізамов зазначають, що педагогічна ситуація - явище об'єктивне і може перетворитися на суб'єктивне лише після усвідомлення та сприйняття його студентами. Ситуація, на думку вчених, стимулює мислення студентів, наближує навчальну діяльність до наукового пошуку, певною мірою знайомить з етапами, методами, засобами наукового пізнання i, безумовно, готує студентів до майбутньої професійної діяльності [4].

У деяких дослідженнях (О. Дубасенюк, В. Ковальчук) «педагогічну ситуацію» пояснюють як детерміновану соціальними чинниками мету професійної діяльності вчителя, яка передбачає різнобічне розкриття i збагачення особистісного потенціалу кожного вихованця у процесі його життєдіяльності; або тлумачать як сукупність зовнішніх і внутрішніх чинників, що детермінують активність суб'єкта. Педагогічна ситуація або задача включає в себе мету, умови (відоме) й шукане (невідоме), яке міститься у запитанні. Ці елементи перебувають у певних зв'язках і залежностях між собою, за допомогою яких здійснюється пошук і виявлення невідомих елементів через задані. Тому педагогічна ситуація утворюється у процесі усвідомлення проблемної ситуації та співвідношення іï задля навчання та виховання.

Здійснюючи аналіз В. Нікандров цікавою вважає гіпотезу «компактності образу» Е. Бравермана та концепцію М. Бонгарда, згідно 3 якою людина жодну задачу не розв'язує як абсолютно нову, а використовує свої здібності «розпізнавати» подібні ознаки поміж уже існуючими та будувати аналогії, спираючись на абстрагування [5].

А. Вербицький визначає два типи норм, яким підпорядковується розвиток особистості спеціаліста під час моделювання педагогічної ситуації: компетентних предметних дій та соціальних відносин колективу. За цих умов формуються соціальні риси та характер спеціаліста. А. Вербицький наголошує на позитивності педагогічних ситуацій, які стають немовби інструментом формування особистості професіонала.

Н. Кузьміна вважає, що педагогічна ситуація стимулює пошук шляхів подолання труднощів під час педагогічної діяльності, зокрема, найкращого способу досягнення певного результату, тому розв'язання педагогічних ситуацій - це водночас і пошук шляхів подолання труднощів, i процес досягнення певної виховної мети [6, с. 227-228]. 
На основі зазначених вище праць педагогічною ситуацією будемо вважати взаємодію між учителем та учнем, а в нашому випадку між викладачем та студентом, у результаті якої відбувається виховний i навчальний вплив на студентів.

Існує низка класифікацій педагогічних ситуацій, які конституються на різних підходах. Класифікації можна типізувати за окремими ознаками:

- управлінням навчальною діяльністю - аналітичні, проективні, ігрові (Ю. Кулюткін, Г. Сухобська);

- завданнями - відповіді на запитання, вибір доцільного розв'язку, самостійне формулювання проблеми, психолого-педагогічна характеристика суб'єктів і об'єктів виховання, розв'язок педагогічних ситуацій на основі педагогічних знань, прогнозування поведінки, пошук педагогічних ситуацій на основі педагогічних джерел, педагогічної практики, самоаналіз особистості в педагогічній ситуації, намітити план самовиховання тощо (В. Сластьонін);

- місцем виникнення і протікання - дидактичні, виховні, навчально-виховні,

- рівнем проективності - жорстко задані, некеровані та керовані, за складом учасників виховного процесу, за суперечностями (В. Безрукова);

- способом розв'язання - ситуації корекції, самоорганізації, за провідною педагогічною задачею, за етапами, за видом організаційної форми, що лежить в основі ситуації, за рівнем розвитку особистості й колективу та виховними перспективами (Л. Гордін, Х. Штольц);

- метою діяльності вчителя - стратегічні, тактичні, оперативні (В. Сластьонін);

- критерієм функціональності - навчальні, критерійні, дидактичні, виховні тощо (Г. Балл);

- критерієм виконання вихованцями навчальних завдань, рівнем успішності, за способом порушення вихованцями правил поведінки ситуації-конфлікти поведінки, ситуації-конфлікти в діяльності (М. Рибакова);

- структурними i функціональними властивостями, за характером взаємодії зовнішніх і внутрішніх умов - узгоджена взаємодія, неузгоджена, суперечлива (О. Дубасенюк);

- метою і спрямованістю взаємодії, за способом взаємодії, за змістом взаємодії, за семантикою взаємодії, за характером взаємодії (А. Бойко);

- часовим критерієм - екстремальні та неекстремальні (Б. Гершунський);

- провідними впливовими чинниками - ситуації, що виникли внаслідок впливу сім'ї, ЗМІ, народних традицій, релігії, мистецтва тощо

- системою відносин - батьки-учень, учитель-батьки, учень-учитель, учень-учень, за характером діяльності вчителя - авторитарно-, демократично-, нейтрально стильові; за способом розв'язання - орієнтаційні, аналітичні, проектувальні, організаторські, оцінні (В. Ковальчук).

У навчальній діяльності студентів моделювання застосовується переважно в процесі переробки інформації про деякі властивості об'єкта вивчення. Майбутній учитель під час теоретичної підготовки до превентивної діяльності з підлітками девіантної поведінки моделює діяльність неповнолітніх і сам об'єкт пізнання, тобто використовує виділені форми моделювання. 
Труднощі моделювання пов'язані з вибором психолого-педагогічних ситуацій та форм їх втілення. Отже, цінність змодельованих ситуацій полягає в тому, що педагогічні ситуації, які використовуються в процесі підготовки вчителя, $\epsilon$ як проміжна ланка між педагогічною теорією i безпосередньою роботою з підлітками девіантної поведінки; педагогічні ситуації, які використовуються в процесі підготовки вчителя до превентивної діяльності, за своїм змістом є навчальними.

Для успішного навчання студентів моделювати педагогічні ситуації превентивної спрямованості враховувати те, що майбутній учитель має розуміти і вбачати неминучість зустрічі зі складними ситуаціями в педагогічній роботі, осмислювати реальні причини їх виникнення, побачити труднощі розв'язання та необхідність оволодіння засобами їх попередження.

Моделювання педагогічних ситуацій регламентується певними правилами, які відображають реальні умови і закономірності. Насамперед потрібно звернути увагу на такі 3 них: чисельність і різноманітність реальних педагогічних ситуацій; якісні відмінності об'єктів, стосовно яких приймаються рішення; специфіка самого процесу прийняття таких рішень характеризується недостатньою визначеністю даних, схоластичним характером багатьох педагогічних явищ, індивідуальними особливостями суб'єктів навчального процесу.

Виходячи зі специфіки формування педагогічної компетентності майбутнього вчителя технологій при роботі 3 підлітками девіантної поведінки, ми структурували групи педагогічних ситуацій превентивної спрямованості Отже:

I група - ситуації, спрямовані на адаптацію підлітків 3 девіантною поведінкою до демократичного стилю життя;

II група - ситуації, спрямовані на надання підліткам 3 девіантною поведінкою психологічної підтримки та педагогічної допомоги;

III група - ситуації, спрямовані на формування у підлітків людських цінностей;

IV група - ситуації, присвячені аналізу підліткової субкультури як умові самовизначення та саморозвитку підлітків з девіантною поведінкою;

$\mathrm{V}$ група - ситуації, спрямовані на формування у підлітків 3 девіантною поведінкою позитивної Я-концепції.

Далі подаємо приклади педагогічних ситуації превентивної спрямованості та їх моделювання в процесі педагогічної підготовки майбутніх учителів при вивченні загальної педагогіки.

\section{"Педагогічна майстерня"}

Mema: 3'ясувати причини виникнення проблемної ситуації; застосувати педагогічні прийоми у розв'язанні складних виховних завдань; проаналізувати ситуацію, виробити власну думку, прокоментувати iі; знайти правильний спосіб власної поведінки в конфліктній ситуації. Група студентів обирає для розгляду 1-2 ситуації. На розгляд кожної ситуації дається 5 хвилин. 
Після цього учасниками розробляються поради молодому класному керівнику щодо розв'язання конфліктних ситуацій, які можуть виникнути під час роботи з девіантними підлітками.

Ситуація 1. Хлопцеві 15 років, закінчив 9 класів. 33 класу почав палити, іноді й випивати. Це було бажання наслідувати «передових». Став гірше навчатися, пропускав уроки, у тому числі й фізичну культуру, брав участь у безглуздих бійках. Із сином серйозно поговорив батько, запропонував зайнятися спортом, відвідувати секцію. Окрім цього, поставив на подвір”і турнік, купив гирі, еспандер, гантелі. Згодом син записався до секції боксу і за рік став чемпіоном школи.

Поміркуйте:

1. Як спільними зусиллями сім’ї та школи боротися за здоровий спосіб життя?

2. Чому дорослі не завжди досягають подібного успіху в роботі 3 підлітками?

Ситуація 2. ... Раніше у Толі все було гаразд. Мама не працювала i дуже багато часу приділяла йому. Потім пішла працювати, і відразу в сім'ї виникли проблеми. Стала помічати в поведінці сина різкі перепади настрою. Хлопця ніби підмінили: він був то дуже збудженим, то впадав у депресію.

Поміркуйте:

1. Про які недоліки у вихованні дитини свідчить ця ситуація?

2. Проаналізуйте поведінку хлопця. Подумайте, які навички самоконтролю розвинуті у нього добре, а які - недостатньо?

3. Які методи доцільно застосовувати для формування у підлітків навичок самоконтролю?

Ситуація 3. Останнім часом загострилися відносини в сім'ї. Справа в тому, що син, якому 13 років, росте кволим, часто хворіс. Усі спроби батька заохотити його до занять спортом, розпочати, принаймні, з десятихвилинної ранкової гімнастики наштовхуються на його вперте небажання, іноді озлоблення. Більше того, мама горою стоїть на охороні його вдаваного спокою: «Не чіпляйся, нехай дитина краще довше поспить». Такі ситуації закінчуються розмовою на високих тонах, сваркою, але головне - батька турбує здоров'я сина. Бачить довкола активних, рухливих, здорових дітей, а синові допомогти не може.

Поміркуйте:

1. Дайте оцінку позиціям членів сім'ї у наведеній ситуації.

2. Як би ви діяли в такому випадку?

3. Обгрунтуйте необхідність єдиних вимог до дітей у сім'ї.

4. Як досягти цієї єдності в фізичному вихованні дітей, формуванні їх здорового способу життя?

\section{Ситуації морального вибору для підлітків}

Наведені педагогічні ситуації можуть застосовуватися вчителем як на етапі констатації задля вивчення ставлення підлітків до моральних норм, що визначають наявність поваги до батьків і старших у сім'ї, так і задля того, 
щоб сформувати в дітей ціннісні ставлення до батьків і старших. У першому випадку діти дають відповіді на запропоновані педагогічні ситуації індивідуально (учитель заздалегідь готує анкети). За відповідями оцінюється рівень сформованості поваги до батьків.

У другому випадку вчитель використовує колективну форму роботи 3 підлітками - зачитуючи ситуації, пропонує дітям проаналізувати кожну і вибрати правильне рішення.

1. Таня запрошена на день народження до подруги. Вона одягає святкову сукню, робить модну зачіску і вже уявляє себе на святі. У цей час приходить 3 роботи мама і відразу ж лягає в постіль: У неї висока температура, загальне нездужання - усі ознаки грипу. Як би ви вчинили на місці дівчинки?

a) не звернули б уваги на мамин стан і пішли б у гості;

б) для «пристойності» поспівчували б мамі, але пішли б у гості;

в) приготували б мамі ліки, чай, потім пішли б на день народження;

г) залишилися б удома, щоб лікувати маму.

2. Батьки запланували у вихідні на присадибній ділянці садити картоплю. Владислав знає, що потрібна його допомога, але їхати не дуже хочеться - $є$ приємна перспектива побути вдома на самоті, послухати музику, відпочити. Як би ви вчинили?

a) категорично відмовилися б їхати;

б) чемно відмовилися, пославшись на те, що незабаром іспит і слід готуватися до нього;

в) поїхали б з батьками на ділянку, але без усякого бажання працювати;

г) охоче поїхали б допомагати.

Отже, запропонована система моделювання педагогічних ситуацій превентивної спрямованості вчить майбутніх педагогів дослідницькій діяльності, задає 3 наукової точки зору зміст i порядок вивчення педагогічних явищ у конкретній ситуації, в процесі безпосередньої роботи.

Висновки та перспективи подальших розвідок. Як бачимо, процес формування педагогічної компетентності залежатиме від умінь студентів моделювати педагогічні ситуації превентивної спрямованості. Використовуваною $є$ широка практика використання методу моделювання педагогічних ситуацій у навчально-виховному процесі сучасної школи, проте проблема використання методу моделювання педагогічних ситуацій у процесі готовності студентів до здійснення превентивної діяльності $\epsilon$ недостатньо розробленою та нині потребує розроблення. Створення в навчально-виховному процесі вищої школи ситуацій, які моделюють майбутню професійно-педагогічну діяльність студентів, на нашу думку, забезпечить формування їхньої педагогічної компетентності.

\section{Література}

1. Антропова Л. В. Решение педагогических задач / Л. В. Антропова // Педагогическая техника. - 2000. - № 2. - С. 191-200. 
2. Бордовская Н. В. Педагогика: [учебник для вузов] / Н. В. Бордовская, А. А. Реан. - СПб. : Питер, 2001. - 304 с.

3. Введенский В. М. Моделирование профессиональной компетентности педагога / В. М. Введенский // Педагогика. - 2003. - № 10. - С. 51-55.

4. Власенко О. М. Формування моральних цінностей у майбутніх учителів засобами моделювання педагогічних ситуацій: дис. ... кандидата пед. наук : 13.00.07 / Власенко Ольга Миколаївна. - Житомир, 2005. - 223 с.

5. Никандров В. В. Метод моделирования в психологии: [учеб. пособие] / В. В. Никандров. - Спб. : Речь, 2003. - 55 с.

6. Постова С. Моделювання педагогічних ситуацій як засіб підготовки вчителів до педагогічного спілкування / С. Постова // Педагогіка. - 2011. - №21. - С. 227-233.

7. Спирин Л. Ф. Анализ учебно-воспитательных ситуацій и решение педагогических задач / под ред. В. А. Сластенина. - Ярославль : Изд-во Яросл. пед. инстта, 1974. - $130 \mathrm{c}$.

Стаття надійшла до редакції 23.05.2012 p.

О. Б. Лоштун, кандидат пед.наук, асистент, Криворізький педагогічний інститут ДВНЗ «Криворізький національний університет»

\title{
ПРИНЦИПИ ТРЕНІНГОВОЇ РОБОТИ В СИСТЕМІ ФОРМУВАННЯ ПРОФЕСІЙНОЇ КОМПЕТЕНТНОСТІ МАЙБУТНЬОГО ВЧИТЕЛЯ
}

\begin{abstract}
Лочтун О. Б. Принципи тренінгової роботи в системі формування професійної компетентності майбутнього вчителя.

Статтю присвячено розв'язанню проблеми використанню тренінгу у професійній підготовиі майбутніх учителів. Автором проаналізовано стан проблеми у психолого-педагогічній літературі та визначено принциии реалізащї тренінгових занять у вищій школі.

Ключові слова: професійна компетентність, тренінг, принципи тренінгу.

Лочтун О. Б. Принщипь тренинговой работь в системе формирования профессиональной компетентности будущего учителя.

Статья посвящена решению проблемь использования тренинга в профессиональной подготовке будущих учителей. Автором проанализировано состояние проблемы в психологопедагогической литературе и определены принципы реализации тренинговых занятий в высшей школе.

Ключевые слова: профессиональная компетентность, тренинг, принцииы тренинга.

Loshtun $O$. Principles of training in the formation of professional competence of future teachers

The article is devoted to solving the problem of training in the training of future teachers. The author analyzes the problems in the psychological and educational literature and defines the principles of the implementation of training sessions in high school.
\end{abstract}

Key words: professional competence, training, training principles.

Постановка проблеми. Сучасна вища освіта, як зазначається в Національній доктрині розвитку освіти України у XXI столітті, має забезпечити підготовку активного, самостійного, творчого фахівця, здатного до постійного пошуку нестандартних способів розв'язання будь-якого виробничого завдання, використання досягнень науково-технічного прогресу, реалізації та самореалізації своїх сутнісних сил у різних видах діяльності.

Проте для вищої школи залишається характерною традиційно сформована система підготовки майбутнього вчителя, що припускає 